原著論文

\title{
皮膚細菌感染症の新臨床評価法の検証試験
}

\section{Validation of a Novel Guideline for Clinical Trial of Antimicrobials in Canine Bacterial Pyoderma}

\author{
岩㟝利郎 $*$ 永田雅彦 大室農夫 安藤 純 \\ 日本獣医皮膚科学会新臨床評価法検証委員会
}

\author{
Toshiroh Iwasaki*, Masahiko Nagata, Tamio Ohmuro, Jun Ando \\ Committee for Validation of the New Clinical Assessment in Japanese Society of Veterinary Dermatology
}

\begin{abstract}
要＼cjkstart約: 日本国内では犬の細菌性膿皮症に対する動物用抗菌剂の臨床試験基準がこれまで存在せず， 客観的な評価が十分ではなかったために新たなガイドラインが動物抗菌剂研究会により示された。こ のガイドラインが臨床的に適切かどうかを実際の細菌性膿皮症症例を用いて検証したところ，発赤， 丘疹/膿疮, 痂皮, 脱毛, 腫脹/熱感, 疼痛の各項目に対するスコア，ならびに光れらの総合スコ アの評価で 2 人の異なる獣医師間の評価に相関性がみられた。また，従来の獣医師による評価を行 い, 弚れとも比較したところやはり両方の評価法間に相関性がみられた。したがって，新規の臨床 試験基準は科学的に妥当と認められ，従来の評価方法と比較して矛盾はないものと考えられた。 キーワード：ガイドライン，抗菌剂，細菌性膿皮症
\end{abstract}

\begin{abstract}
There have been no guidelines regarding clinical trials of antimicrobials for canine pyoderma in Japan. A novel guideline for evaluating clinical signs is introduced by the Japanese Society of Antimicrobials for Animals to improve the objective clinical evaluation. This guideline was validated using clinical cases of canine pyoderma. There was statistically significant correlaiton in clinical scores of erythema, papule/pustule, crust, hair loss, swelling, pain and total scores between two veterinarians. Then, the conventional evaluation method and a novel guideline were compared by the veterinarian, there was also significant correlation between two evaluation methods. From these results, a novel evaluation method in the newly proposed guideline is suggested to be appropriate to apply for clinical trial of canine pyoderma, and there seems to be minimum inconsistency between a conventional and a novel clinical evaluation system.
\end{abstract}

Key words: guideline, antimicrobial, pyoderma

(Jpn J Vet Dermatol 2008, 14 (2): 71-75)

\section{緒 言}

動物抗菌剂研究会では平成 16 年より動物用抗菌剂
の皮膚細菌感染症の臨床試験に関するガイドラインを 委員会に諮問していたが, 平成 17 年 12 月に委員会よ り答申があり,さらにこのガイドラインは「動物抗菌

*連絡先 : 岩㟝利郎 (東京農工大学獣医内科学研究室) ₹ $183-8509$ 東京都府中市幸町 3-5-8

TEL/FAX 042-367-5777Ｅ-mail: bpag2180@cc.tuat.ac.jp

*Correspondence to: Toshiroh Iwasaki (Laboratory of Veterinary Internal Medicine, Tokyo University of Agriculture and Technology)

3-5-8 Saiwai-cho, Fuchu, Tokyo 183-8509, Japan 
表 1 症状の程度の基準

\begin{tabular}{|c|c|c|c|}
\hline スコア & 0 & 1 & 2 \\
\hline 発赤 & 通常の色調 & 発赤があるとわずかに認識できる & 淡い赤色 \\
\hline 丘疹／膿庖 & なし & 痂皮を付着した膿庖 & 発赤を伴う丘疹 ～～～～～～～～～～疗 \\
\hline 痂皮 & なし & わずかに痂皮がみられる & 痂皮が散発してみられる部分がある \\
\hline 脱毛 & なし & 掻破痕がみられるが被毛は抜けていない & 近接して観察すると脱毛か認識できる \\
\hline 腫脹／熱感 & なし & わずかに腫脹がある & 触れてわずかに熱感がある \\
\hline 疼痛 & $\begin{array}{l}\text { 患部に触れても } \\
\text { 反応がない }\end{array}$ & 患部に触れるとわずかに反応がある & 患部を舐める \\
\hline 膿汁 & 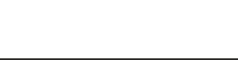 & 漿液樣の膿汁 & 黄色の膿汁 \\
\hline スコア & & 3 & 4 \\
\hline 発赤 & \multicolumn{2}{|c|}{ 明らかな赤色 } & 鮮やかな赤色で熱感がある \\
\hline 丘疹／膿庖 & \multicolumn{2}{|c|}{ 先端に膿を付着した丘疹 } & 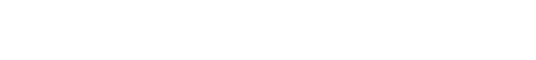 \\
\hline 痂皮 & \multicolumn{2}{|c|}{ 痂皮が集合してみられる部分がある } & 痂皮が連続的にみられる \\
\hline 脱毛 & \multicolumn{2}{|c|}{ 完全な脱毛はないが近接せずに脱毛か認識できる } & 完全な脱毛領域がある \\
\hline 腫脹／熱感 & \multicolumn{2}{|c|}{ 腫脹と熱感はあるが強くはない } & 腫脹が強く，触れて熱感がある \\
\hline 疼痛 & \multicolumn{2}{|c|}{ 患部に触れると嫌がり，舐める } & 常に患部を気にして舐める \\
\hline 膿汁 & \multicolumn{2}{|c|}{ 瘻管があり黄色または血樣の膿汁がときに排出される } & 瘻管から血樣の膿汁が常に排出される \\
\hline
\end{tabular}

会報」に掲載されている1)。このガイドラインを受け て獣医皮膚科学会では, 本臨床評価ガイドラインに 沿って犬の皮膚細菌感染症を評価し, 本評価方法の妥 当性について，これまで行ってきた評価法と比較し， また観察者の違いによるバイアスの有無について検証 したので報告する。

\section{材料と方法}

試験はガイドラインに示された方法に従って，臨床 症状を評価した。以下の基準を満たす動物患者, 症状 を皮膚細菌感染症 (以下膿皮症) と診断して本試験に 組み入れ，新臨床評価方法を用いて，2 時点で評価し た。さらに以下の条件で動物を検証試験に組み入れた。

(1)治療に用いる抗菌剂の種類は問わない

(2)治療する期間は問わない

(3)併用する薬剂は問わない

(4)表在性膿皮症あるいは深在性膿皮症を対象とする

1. 膿皮症の症状に関する基準

1) 表在性膿皮症

毛包炎 (毛包一致性の丘疹あるいは膿疮) が次第に 融合して発生する， いわゆる表皮小環 (環状の痂皮を 伴いわずかに隆起する発赤で, 中心部は治癒傾向がみ
られ, 中心部の色調は正常皮膚色あるいは色素沈着し ており，紅斑は環状に周囲へ拡大する），あるいは膿 疱, 膿痂疹を伴う発赤である。痒みおよび脱毛か認め られることがある。

2) 深在性膿皮症

発赤, 腫脹が見られ, 浸潤を触れることがあり，瘻 管を形成し膿樣あるいは血樣物質を排出することがあ る。瘻管のみられることがある。痒み, 疼痛がみられ ることがある。

\section{2. 膿皮症の検査の基準}

上記の臨床症状を示す症例を，以下の基準を満たす ことにより膿皮症と判定し，検証試験に組み入れた。

1) スクレーピング (皮膚掻爬検査) が陰性であること 外部寄生虫および皮膚系状菌の原因を除外するため にスクレーピングを行い，陽性であったものは試験に 組み入れなかった。

2) マラセチアの検査が陰性であること

マラセチア性の病変を除外するために, 病変部の細 胞診を行った。対物100倍の油浸レンズで観察し，1視 野で5個以上のマラセチアが観察されたときはマラセ チアの増殖が疑われるため, 試験に組み入れなかった。

3) 塗抹細胞診で細菌が認められること

病変部からの滲出物や膿蕉あるいは膿疱, 膿痂疹の 
表 2 症状の範囲の基準

\begin{tabular}{|c|c|c|c|c|c|}
\hline スコア & 0 & 1 & 2 & 3 & 4 \\
\hline 発赤 & なし & 1\%末満 & $\begin{array}{l}\text { 体表面積 }{ }^{1} \text { の } \\
\text { 1\%以上 , } 5 \% \text { 末満 }\end{array}$ & $\begin{array}{l}\text { 体表面積の } \\
\text { 5\%以上, 10\%未満 }\end{array}$ & 体表面積の 10\%以上 \\
\hline 丘疹／膿庖 & なし & 1，2個 & 3,4個 & 5個以上 , 9個以下 & 10個以上 \\
\hline 痂皮 & なし & 帽針頭大まで & 拇指頭大まで & 合計して 手掌大まで & 合計して 手掌大以上 \\
\hline 脱毛 & なし & $\begin{array}{l}\text { 全面的な } \\
\text { 被毛の再生 }\end{array}$ & $\begin{array}{l}\text { 体表面積の } \\
1 \% \text { 以上, } 5 \% \text { 未満 }\end{array}$ & $\begin{array}{l}\text { 体表面積の } \\
5 \% \text { 以上 , 10\%末満 }\end{array}$ & 体表面積の 10\%以上 \\
\hline 腫脹／熱感 & なし & 帽針頭大まで & 拇指頭大まで & 合計して 手掌大まで & 合計して 手掌大以上 \\
\hline 疼痛 & なし & 1力所 & 2力所 & 3力所から 9力所 & 10力所以上 \\
\hline 膿汁 & なし & $\begin{array}{l}\text { ガーゼにわずか } \\
\text { に付着する }\end{array}$ & $3 \mathrm{ml}$ 末満 & 3から $10 \mathrm{ml}$ 末満 & $10 \mathrm{ml}$ 以上 \\
\hline
\end{tabular}

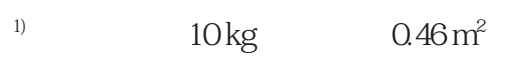

内容物，表皮小環の痂皮を剥がしたあとのびらん面を スライドガラスに塗抹し, 適切な染色液で染色し, 対 物 100 倍の油浸レンズで観察して1視野に少なくとも 数個程度の細菌が観察されるものを試験に供した。

4) 細菌培養

細菌培養は実施しなかった。

3. 妥当性の評価方法

1) 以上の条件に適合する症例を膿皮症とし，表1およ び表 2 に示すような新臨床システムの評価法に従 い, 少なくとも2回, 2 人の獣医師が独立して症状 を評価した。2人の評価は同一日に実施した。発赤， 脱毛, 痂皮, 丘疹/膿疮, 腫脹/熱感, 疼痛, 膿汁 の7項目に関して，「症状の程度」と「症状の範囲」 を0点から 4点で表現し, 光の積を各症状のスコア とした。したがって, 各症状の個別スコアは最低0 点から最高16点までであった。各個体に対しては各

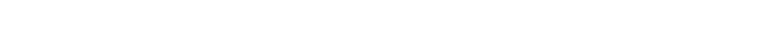
計して算出した。表在性膿皮症では発赤, 丘疹/膿 疮, 脱毛, 痂皮4項目を評価し, 深在性膿皮症では すべての項目を評価したため, 最高スコアは表在性 膿皮症では64点，深在性膿皮症では112点であった。

2) これまで一般的に用いられてきた, 獣医師による総 合的臨床評価を2回目の観察日あるいは最終評価日 に実施し，これらの評価を症状の改善度に従って， (1)著効, (2)有効, (3)やや有効, (4)無効, (5)悪化と表 した。
それらのデータから

(1) 治療前と治療後のスコア改善率 \{(治療前スコア 治療後スコア) / 治療前スコア $\}$ と獣医師による主 観的な臨床評価の相関関係について Spearman の相 関係数を用いて統計的にしらべた。

(2) 各症例における評価者間に差がないかどうかをみる ために，2 人の評価者間のスコアの相関関係を Spearmanの相関係数でしらべた。

\section{結 果}

試験実施施設は4施設であり，光れらの施設の総症 例数は24症例であった。症例の内訳は雄21頭, 雌3頭 であり，年齢は2.5力月齢から15歳齢までの分布で，光 の平均年齢は6.4歳であった。犬種はシーズー頭，ミ ニチュア・ダックスフント 2 頭 , ミニチュア・シュナ ウザー2頭，ゴールデン・レトリバー2頭，アメリカ ン・コッカースパニエル 2 頭, キャバリア・キング チャールズスパニエル2頭, 兴の他10種各1頭ずつで あった。また診断は表在性膿皮症または膿皮症であっ た。再観察までの期間は7日間から 44日間であった。

各症例の治療前の症状ごとの臨床スコアは2人の獣 医師により評価され, 各症状のスコア平均值と標準偏 差は発赤が $4.2 \pm 3.2$, 脱毛が $4.6 \pm 3.9$, 痂皮が $2.9 \pm$

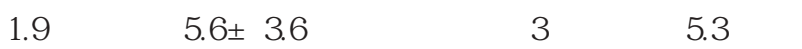
痛は 3例のみで 4.2 , 膿汁は 3例で 1.6 , 臨床スコアす

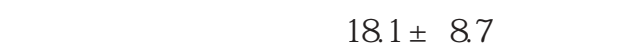

治療後の症状を獣医師2名によってスコア化が可能 


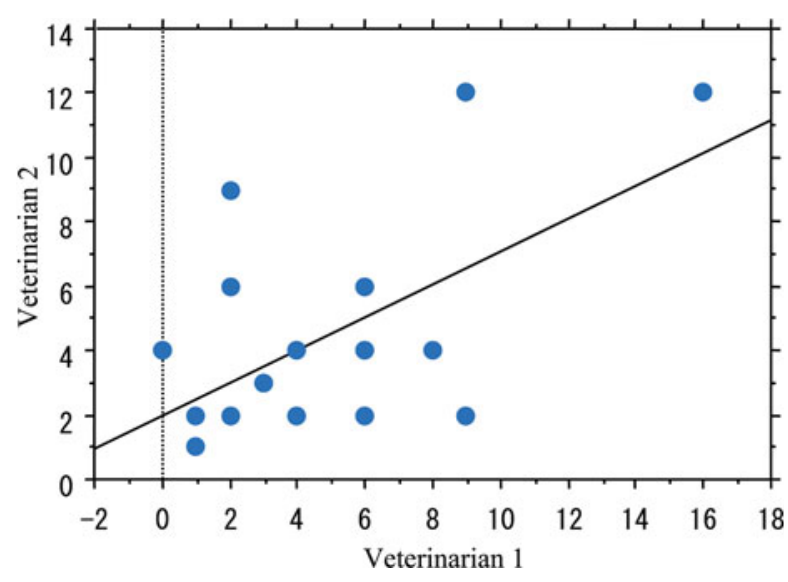

Fig. 1a. Relationship of clinical scores by 2 different veterinarians (Erythema).

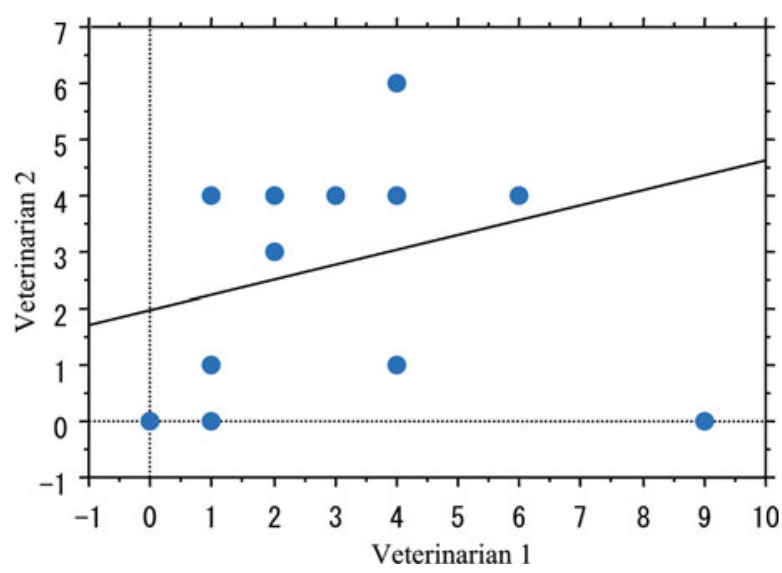

Fig. 1b. Relationship of total clinical scores by 2 different veterinarians (Crust).

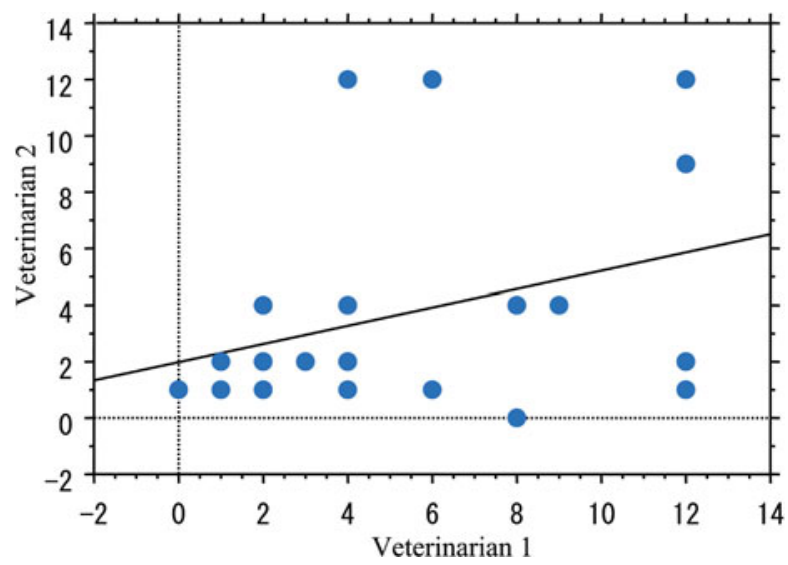

Fig. 1c. Relationship of total clinical scores by 2 different veterinarians (Hair loss).

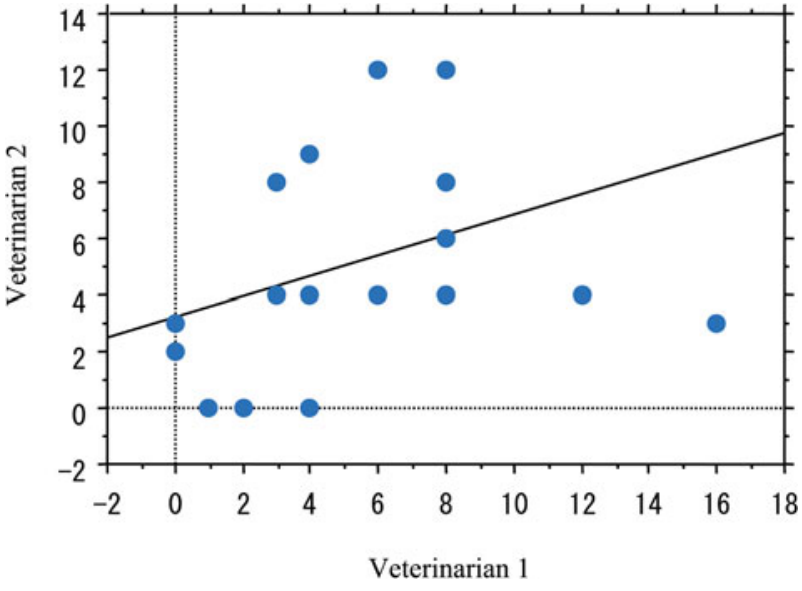

Fig. 1d. Relationship of total clinical scores by 2 different veterinarians (Papule/Pustule).

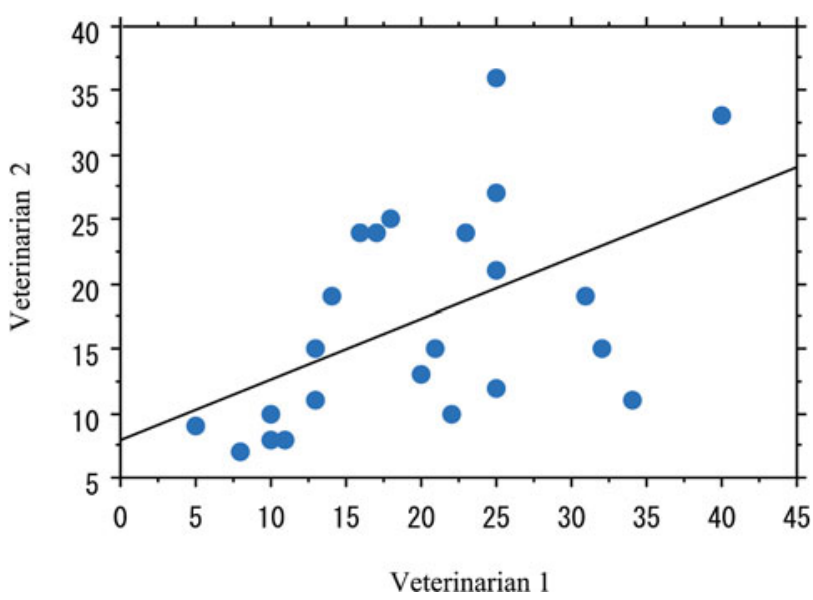

Fig. 1e. Relationship of total clinical scores by 2 different veterinarians.

であったのは15例であった。治療後に来院しなかった ものが5例，治療後の症状を獣医師 1名しか観察して いないものが4症例あった。治療後の総合スコアをこ

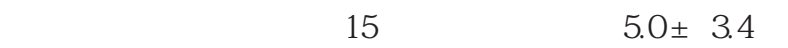
著しく低下していた。

発赤症状に関する 2 人の評価者間の相関は， Spearmanの順位相関では危険率5\%以下で相関がみら れた (Fig. 1a)。同樣に痂皮 (Fig. 1b) を除く脱毛 (Fig. 1c), 丘疹/膿疮 (Fig. 1d), 腫脹・熱感, 疼痛の項目 で同樣に統計学的な相関か認められた。また，これら を合計した総合スコアを2人の評価者間で比較したと きも同樣に有意な相関が認められた (Fig. 1e)。

スコア改善率 $\{($ 治療前スコア - 治療後スコア $) /$ 治 療前スコア\} と従来の臨床評価法 (1〜 5) の結果との 


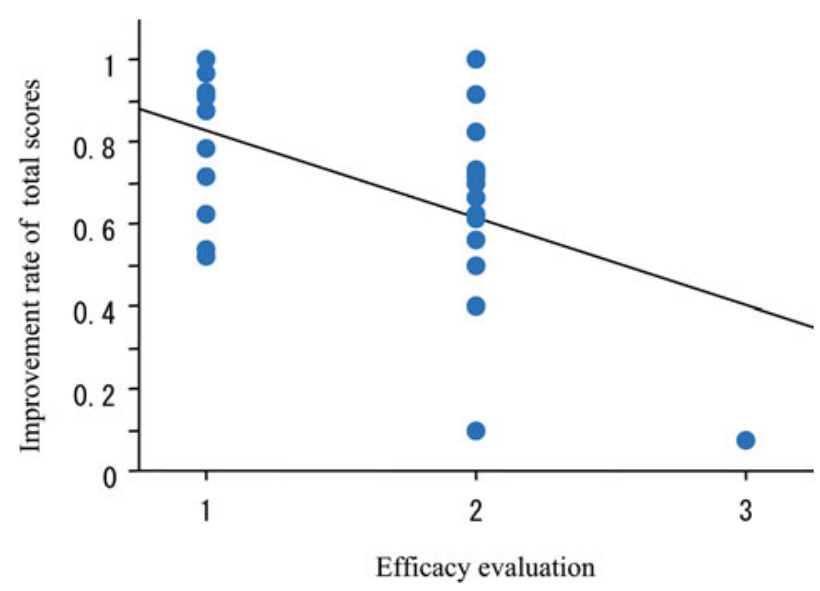

Fig. 2. Relationship between improvement rate of total clinical scores and efficacy evaluation by veterinarian.

相関関係について, Spearmanの順位相関係数を用いて 検定を行った。両評価方法は $5 \%$ 以下の危険率で正の 相関があると判定された (Fig. 2)。

\section{考 察}

薬斉の臨床試験は薬物治療に対するエビデンスを得 るために最も大事な試験であり，臨床試験には科学的 に統一された見解が必要である。なかでも臨床症状の 評価方法はこれまでの試験においても一致した基準が なく，試験を超えた評価は困難であった。

ヒトにおける抗菌剤に対する臨床試験は平成 10 年 に厚生省医薬安全局審査管理課長から出された通達に よって国際的にハーモナイズされた「抗菌薬臨床評価 のガイドライン」に従い方向付けがなされている2)。こ れにより臨床試験の進め方，臨床評価の具体的方法， 適応菌種, 菌群, 菌族の決定などが詳細に科学的に定 められている。

一方, 臨床獣医学領域では科学的なコンセンサスを 経た臨床試験のガイドラインは現在にいたるまで作成 されておらず，経験的なあるいは既存の薬斉の臨床試 験を踏襲した試験プロトコールを主体として実施され ていた。このような多くの臨床試験のプロトコールで は，獣医師か評価した改善率をもとに有効性を評価し ており，客観的な視点に欠けている可能性がある。

この点を改善するべく, 動物用抗菌剂研究会臨床評
価 (小動物) 検討委員会は抗菌斉の臨床試験の評価法 (ガイドライン)を新たに作成した。著者らはこの新規 のガイドラインか臨床的あるいは科学的に則して妥当 であるかどうかを，実際の犬の膿皮症の症例を用い て，2人の獣医師の観察結果を基にして検証した。

検証の最初の視点は, 新規の評価方法か観察者の間 に有意な個人差を生じるかどうかであり，これには 2 人の獣医師が同時に同じ個体および病変を観察し，ス コア化することから調べた。各皮疹におけるこれら 2 人のスコアの相関を調べたところ，痂皮以外の発赤， 脱毛, 丘疹, 腫脹・熱感, 疼痛の項目で有意な相関関 係か認められた。また , これらのスコアを合計した総 合スコアを2人の獣医師間で比較したところ，2人の獣 医師間に有意な相関関係か認められた。このことから 膿皮症の症状を新規の方法て臨床評価したときに，観 察者間に生じるバイアスは最小限であると考えられ た。しかし，今回の症例では痂皮を生じるような重篤 な膿皮症が少なかったことから, 痂皮の項目には十分 な検証ができなかったと考えられ，今後さらに症例数 を増加させた試験が必要であるかもしれない。

次に現在まで行われてきた代表的な方法を用いた評 価結果と, 新規の評価方法を比較し, 両者の相関関係 を観察した。現在まで行われてきた方法では著効を5， 悪化を1と置き換え，兴の間は有効を4, やや有効を 3 ， 無効を2として評価し，新規の方法のスコア改善率と 比較した。弚の結果，両者の間には正の相関か認めら れ，新規の方法て評価した結果はこれまでの評価方法 と矛盾をきたすものではないと考えられた。

以上より，新規に作成された動物用抗菌剂の臨床試 験ガイドラインに従った臨床評価方法は，これまでの 評価方法との矛盾をきたさず，また評価者間のバイア スが少なく，評価方法として妥当であると考えられた。

引用文献

1) 岩㠃利郎, 浅井鉄夫, 内田幸治, 片岡 康, 桑野 昭, 澤田拓士, 中田勝久, 深田恒夫 . 2008 . 犬の細菌性 膿皮症および細菌性尿路感染症を適応症とする動物 用抗菌性物質製剂の臨床試験実施基準の設定につい て. 動物抗菌剂研究会報 29 (増刊) : 2-13.

2) 新薬臨床試験ガイドライン (日本公定書協会 編) 2001 . pp. 562-588, 薬事日報社, 東京。 